\title{
PRE-SERVICE TEACHERS' PERCEPTIONS ON THE USE OF MOBILE APPLICATIONS FOR LANGUAGE LEARNING
}

\author{
Eka Ananda Putri ${ }^{1}$, Dadang Danugiri ${ }^{2}$, Fauzi Miftakh ${ }^{3 *}$ \\ ${ }^{1}$ (English Education Department, Faculty of Teacher Training and Education, \\ Singaperbangsa University, Indonesia).
}

* Corresponding Author. E-mail: ${ }^{1}$ eputri649@gmail.com

\begin{abstract}
Abstrak
Belajar bahasa saat ini dapat dilakukan dengan banyak cara diantaranya menggunakan teknologi mobile atau telepon genggam dan aplikasinya. Pembelajaran menggunakan aplikasi mobile tidak hanya dapat dilakukan dengan menggunakan pembelajaran bahasa berbasis aplikasi, tetapi juga menggunakan aplikasi umum. Studi kasus deskriptif ini digunakan untuk menyelidiki dan mencari tahu tentang tingkat dan persepsi guru prajabatan tentang penggunaan aplikasi seluler untuk pembelajaran bahasa. Data dari enam guru prajabatan dikumpulkan dengan menggunakan wawancara semi-terstruktur dan kuesioner. Hasil penelitian menunjukkan bahwa semua guru prajabatan memiliki tingkat penggunaan aplikasi seluler yang berbeda untuk pembelajaran bahasa berdasarkan tujuan, tantangan, dan pengalaman mereka. Selain itu, sebagian besar guru prajabatan memiliki persepsi positif tentang penggunaan aplikasi seluler untuk pembelajaran bahasa mereka tentang kesesuaian teknologi seluler tujuan, kesesuaian cabang, dan bentuk aplikasi m-learning dan kecukupan alat komunikasi, temuan mengungkapkan bahwa (1) aplikasi mobile menghilangkan batasan ruang dan waktu; (2) aplikasi seluler dapat diandalkan untuk penggunaan pribadi; dan (3) materi pelajaran dapat dikirim ke siswa melalui aplikasi seluler. Kesimpulannya, penggunaan aplikasi seluler untuk pembelajaran bahasa sangat membantu guru prajabatan.Kata Kunci: belajar bahasa Inggris, aplikasi seluler, belajar bahasa dibantu seluler, guru prajabatan
\end{abstract}

\begin{abstract}
Learning language nowadays can be done by many ways including using mobile technology or mobile phone and its applications. Learning uses mobile applications not only can be done by using app-based language learning, but also using general application. This descriptive case study was used to investigate and find out about pre-service teachers' levels and perceptions on the use of mobile applications for language learning. The data from six pre-service teachers were collected by using semi-structured interviews and questionnaire. The result showed that all of pre-service teachers have different levels of using mobile applications for language learning based on their purposes, challenges and experiences. In addition, most of pre-service teachers have positive perceptions on the use of mobile application for their language learning regarding on aim-mobile technologies fit, appropriate of branch, and forms of m-learning application and tools' sufficient adequacy of communication, the findings revealed that (1) mobile applications remove the limitation of time and space; (2) mobile applications are reliable for personal use; and (3) course materials could be sent to students via mobile applications. In conclusion, the use of mobile applications for language learning are helpful for pre-service teachers.
\end{abstract}

Keywords: English language learning, mobile applications, mobile assisted language learning (MALL), pre-service EFL teachers

\section{Introduction}

In the 21 st century, the accretion of technology is significant increased than ever and it affects many aspects, including mobile technology (Shosha, Mohamed, \& Fayed 2019). Currently, the number of shifting from traditional technologies such as desktop computer toward mobile technologies such as mobile phone or smartphone is tremendously increased over the past 15 years (Klímová, 2017; Loewen, Crowther, Isbell, Kim, Maloney, Miller, \& Rawal, 2019). The use of mobile phone in developed country has surpassed over $90 \%$ of users (Pew Research Center, 2017 and Statista, 2016 cited in Klímová 2017) as well as the increasing of smartphone or mobile phone ownership in society (Klímová 2017; Thedpitak \& Somphong, 2021).

In recent years, the investigation of the use of mobile technology such as mobile phone for language learning have been done by many researchers (Kim, Rueckert, Kim \& Seo 2013). In term of language learning, Rosell-Aguilar (2009) cited in Thedpitak \& Somphong (2021) states that to improve students' linguistic areas, such as vocabulary and follow their needs of target language, which is English, the mobile applications can be downloaded and be available on students' mobile phone. It will make them easier to practice their target language anywhere and anytime. In addition, the use of mobile devices especially mobile applications for language 
Jurnal Edumaspul, 5 (2), Year 2021- 720

(Eka Ananda Putri ${ }^{1}$, Dadang Danugiri ${ }^{2}$, Fauzi Miftakh ${ }^{3}$ )

learning can conduct students to have different environments (Tai, 2012) for learning grammar, listening and speaking (Rueckert, Kiser, \& Cho, 2012) and can afford students in collaborative language learning environments (Kim, Rueckert, Kim \& Seo 2013).

Literature studies show that mobile applications can help and support EFL students' language learning. Ekinci \& Ekinci (2017) investigated perceptions of EFL learners about using specific mobile applications such as DuoLingo, Memrise, Acobot, VoScreen, and English Central for English language learning in Turkey and the result showed that these specific mobile applications give positive effects for students' language learning and their motivation to learn English. Despite there are positive effects of specific mobile applications for students language learning, the study of students' perception on the use of mobile applications in general and not only focus on specific applications for language learning should be investigated. Therefore, to fill this void, this recent study aims to contribute in this topic by investigating and exploring six pre-services teachers' perceptions on the use of mobile applications for their language learning. This study will investigate pre-service teachers from a state university in Karawang.

\section{Mobile-assisted language learning (MALL)}

Twarog \& Preszlenyi Pinter (1988) cited in Hashim et al., (2017) state that MALL's history is started in the 80s with focus on telephone assisted language study to provide distant students to learn language with assistance and feedback then develop with various mobile devices, such as mobile phone. Mobile-assisted language learning (MALL) is a part of Computer-Assisted Language Learning (CALL) that is divided based on MALL's practitioners and MALL is defined in mobile learning and technology-enhanced language learning (TELL) (McCarty, Sato, \& Obari, 2017). Chinnery (2006) cited in Klímová (2017) explains that mobile-assisted language learning is a process of learning language that is assisted through mobile devices such as mobile phone and be done by students. Mobile-assisted language learning (MALL) is primarily related to how students use mobile technologies which is mobile devices such as mobile phone or smartphone to support students' language learning, students' self-learning (Miangah \& Nezarat, 2012; Thedpitak \& Somphong, 2021) and ascertain the benefits of using mobile technologies (Chen, Mayall, York \& Smith, 2019).

Furthermore, Oz (2013) cited in Klímová (2017) propose that mobile-assisted language learning has several characteristics that make it feasible for students to learn language at anywhere and anytime in formal or informal environments. Mehdipour and Zerehkafi (2013) cited in Klímová (2017) register several characteristic of mobile technology, such as mobile phone or smartphone: portability or mobility means mobile technology can be used and be available whenever the users want to learn, individuality means the mobile technology can suit for individual students' needs, unobtrusiveness means students can arrest situations without the mobile technology becomes overly noticeable on the situation, availability means mobile technology can be used anywhere, adaptability means mobile technology can be adapted based on the context and students' needs, persistence means the students can use the technology to manage their learning's time. The next is usefulness that means students can use mobile technology for other needs out of language learning, such as communication, and usability that means the mobile technology can be easily to be used by students.

The use of mobile technology for language learning gives many advantages as well as challenges for students. Students are motivated to build their self-regulated learning and are inspired to have collaborative learning with their peers (Kukulska-Holme \& Shield, 2008; Thedpitak \& Somphong, 2021). For example, Niesner (2010) cited in Kukulska-Hulme (2020) explains that learners can have collaborative learning by joining to the communities of online language learning skills, exchange their knowledge of language learning and practice together with other members in the communities. Moreover, Gafni, Achituv, \& Rachmani (2017) cited in Silva et al., (2019) summarize the advantages of using mobile technology are students have freedom and flexibility to use mobile devices for language learning in their time.

The challenges that might appear during the implementation of MALL can be felt by both students and teachers. The challenges on teachers' side is making mobile learning design that will be suitable for students' needs, students' physical conditions and still teachers can control students' language learning process (Kukulska-Hulme, 2020). Meanwhile, the challenges on students' side are as small-sized of mobile screens that can make students difficult to read the learning materials, the quality of mobile devices used such as limitations of the storage, battery life of mobile devices, unstable connection of internet and students' financial also can be a challenge for mobile language learning by using mobile devices (Miangah \& Nezarat, 2012; Thedpitak \& Somphong, 2021).

\section{Mobile applications and their use for language learning}

Mobile applications and their use for language learning are not only applications that specifically designed for language learning, but also the applications that are not specifically designed for language learning but still can be used to support the language learning process (KukulskaHulme, 2020). Rosell-Aguilar (2017) cited in Thedpitak \& Somphong, (2021) state that there are three types of mobile applications for language learning: applications that specifically design for language learning, general application and translation and dictionary applications. Applications that specifically designed for language learning focus on developing students' language learning such as Duolingo and Edmodo. Duolingo is application focus on developing four English skills. Meanwhile, Edmodo is application that focus on providing course material presented by teachers (Sabila, Pahlevi, \& Miftakh, 2020). In addition, Web applications or web 2.0 platforms can be seen as example of general application used for language learning. Faizi (2017) state that web 2.0 platform or application can be classified into three categories. The first category include Facebook, Google+, 
Jurnal Edumaspul, 5 (2), Year 2021- 721

(Eka Ananda Putri' ${ }^{1}$, Dadang Danugiri ${ }^{2}$, Fauzi Miftakh ${ }^{3}$ )

WhatsApp, Twitter and all the social communication platform that can help people to communicate and interact with others. The second category include online platforms that can share and organize content, such as YouTube and Slideshare. The third category include discussion forums that can produce and edit the contents, such as Wiki, Blogger, and Google Docs. Moreover, Translation apps is a platform that can help students to learn language. Prince (2017) cited in Lake and Beisly (2019) state that translation apps can be used to facilitate communication between teachers and students and help students to understand the meaning of the word then interpret it and the translation application that the most used is Google Translate. In addition, the dictionary applications also can be useful and beneficial for supporting language learning. Bastos \& Machado (2016) state that the dictionary apps be used to support students' language learning and can be used in both formal and informal learning. The dictionary apps can be said as pedagogical tool for students who learn language, for example U-Dictionary apps.

\section{Method}

To get better understanding about pre-service teachers' perceptions on the use of mobile applications for language learning, a descriptive case study was used to investigate and find out pre-service teachers levels and perceptions on the use of mobile applications for language learning. The descriptive case study was chosen because it aimed to present and describe a particular phenomenon (Yin, 2003) cited in Heigham \& Croker (2009).

The participants of this study were six pre-service teachers who majoring English education in a state university in Karawang, Indonesia. This state university was chosen because it consisted some criteria; geographical closeness and easy accessibility. The participants were chosen using purposive sampling because the researcher wanted to investigate the pre-service teachers who use mobile technology especially mobile devices and their apps for supporting their language learning in and out of the classroom.

The data were collected using semi-structured interview adapted from Thedpitak \& Somphong (2021) to find out pre-service teachers' levels of using mobile applications for language learning and questionnaire consisted of 23 questions of mobile perceptions learning scale adapted from Uzunboylu and Özdaml (2011) to find out pre-service teachers' perceptions of using mobile applications for language learning. The data from interview were analyzed using thematic analysis from Braun and Clark (2006) who suggested 6 stages: 1) familiarizing with data; the researchers read the data carefully and re-read the data for a couple of times to get better understanding and to take a note by highlighting some important points from the data, 2) generating initial codes; after familiarizing with the data, the researchers coded the data into several codes, 3) searching for themes; the researchers categorized the data into several themes, 4) reviewing themes; the researchers tried to review the categorized themes to make sure that the data were belong to the particular themes or not, 5) defining and naming these; the researchers started to name every themes of the data; 6) producing the report; the researchers started to produce a report by analyzing and interpreting each themes that have been categorized before. The data from questionnaire were analyzed using descriptive statistic that focused on finding mean from questionnaire.

\section{Findings and Discussions}

\section{Pre-service teachers' levels in using mobile applications for language learning}

1. Purpose of using mobile applications for language learning

Based on the interview sections, most of the participants shared that the purpose of learning language, especially English using mobile applications were to reach the efficient way to learn English and to have more flexibility and easiness in enhancing the level of the target language. One participant said:

"I think the purpose of using mobile
application for language learning is to
have more flexibility and easiness in
enhancing the level of our target
language." (M2)

According to the quote above, the participant stated the benefit of using mobile applications could help them to have the most efficient way, flexibility and easiness to reach their target language, especially in English. These statements were in line with Gafni, Achituv, \& Rachmani (2017) cited in Silva et al., (2019) that summarized the advantages of using mobile technology especially mobile applications for language learning were to have freedom and flexibility to use mobile devices for language learning in their time.

In addition, there were specific English skills that made pre-service teachers use mobile applications for language learning. The specific English skills that have been mentioned in the interview sections were listening skill, speaking skill, reading skill, writing skill and vocabulary. Three participants said:

"Yes, I have. I want to improve my listening and speaking skills. Therefore, I often use YouTube app and Google Translate app that are installed in my mobile phone." (F1)

"I think that I want to improve speaking...the most important of all probably speaking” (F3)

"I might more focus on vocabulary..." (M3)

As for the purpose of using mobile applications, all of the participants responded had positive and similar responses, which is to help and support them learning their target language easily, enjoyable, without the limitation of time. This result showed that the participants used mobile applications as a tool for supporting their language learning and supported by research that was conducted by Hsu (2013) 
that had the same result, which is for supporting students' language learning process. In addition, each of them also had specific English language skills such as vocabulary and speaking skills that they wanted to improve by using mobile applications. This result is similar with Loewen, Isbell \& Sporn (2020) who conducted the research and showed that app-based language instruction such as Duolingo was able to develop students' knowledge of language such as grammar, vocabulary as well as students' speaking ability.

\section{Challenges when learning language using mobile applications}

Based on the interview sections, the participants have faced many challenges when they learnt language using mobile applications. Two of six participants mentioned some challenges that they found and should be faced by them when learning language as showed in the following passages.

"Limited network access, costly, unsupported mobile space storage, distracted from other app notifications." (F1)

"First, the mobile device itself can run the applications or not. Second, I should adapt with the feature of new mobile application that I use. Third, I really depend on good internet connection. Fourth, the disturbing from environment." (M1)

As the following passages above, the two participants mentioned that they mostly found unstable connections when they learn language using mobile applications. Furthermore, for the challenges, this result showed some of challenges that mostly found by them: limited network access, financial problem, unsupported mobile space storage, distracted from other app notifications and environments. This results were in line with Miangah \& Nezarat, (2012) and Thedpitak \& Somphong, (2021) that showed about the challenges students found would be about quality of mobile devices, unstable connection of internet and students' financial.

\section{Experiences when learning language using mobile applications}

In this theme, the researcher showed about preservice teachers' experiences when learning language mobile applications and there were six parts of theme from interview sections.

Based on the interview sections, the participants mentioned some mobile applications that they most used for language learning. These applications included in applications that were designed for learning language such Duolingo and applications that were not designed for language learning such as translation applications and online dictionary, as illustrated by the passages below.

"I usually use Google translate if there are some words that I do not understand. So, I can easily find the meaning of the words and it can add my vocabulary." (F2)
According to the following quotes above, the participant used Google translate to find out the unfamiliar words that they often found when learning language, especially learning English language. Therefore, it helped them to increase their vocabulary. Prince (2017) cited in Lake and Beisly (2019) also stated that translation apps can be used to help students to understand the meaning of the word.

Using application that was specifically designed for learning language like Duolingo has been mentioned by some of the participants. As representative by the statements from F3 about the advantages of using Duolingo.

"I used to use an app called Duolingo. It is an app specifically design to learn languages. It offers the language learning lessons for so many languages, but in my case, I used it to learn English, and a little bit France. I think it was really efficient for me to use that app, not only that the app provided me an easy way to learn English, or in most cases, English vocabularies, but also because the app was installed in my phone, so I could open it anywhere I want, as long as I have internet connection." (F3)

Furthermore, another application that was not specifically designed for language learning was YouTube. Putri, Wijayanto, and Supriyadi (2020) also stated that YouTube could be the application that supported and helped students to learn language and brought enjoyment and excitement when learning using YouTube because they learnt language based on their interest such a watching videos on YouTube, as illustrated by the following quotes.

"I use YouTube for learning English through video, such as English learning videos, actors or singers' interviews, song's lyrics, and movie memes. I think, we can learn English from every kind of videos, as long as the videos spoken in English then it can help us improve our learning skills." (F3)

"Therefore, I love to watch videos on YouTube about how to improve my speaking skill, tips and tricks how to improve speaking skill. Also, I usually do not watch the learning English material, sometime I just watch English videos, such American' talk shows. I want to see how the way they do daily English activity." (M2)

Based on the following quotes above, both of the participants mostly used YouTube because they could learn and could improve their English language skills, through their interest, watching videos on YouTube. This meant that besides YouTube could provide an enjoyment and excitement from its videos, it also could be beneficial and helpful for the participants who wanted to learn language by their interest.

In addition, social networking sites that were not specifically designed for language learning could also be used to help and support the participants to learn their target 
Jurnal Edumaspul, 5 (2), Year 2021- 723

(Eka Ananda Putri' ${ }^{1}$, Dadang Danugiri ${ }^{2}$, Fauzi Miftakh ${ }^{3}$ )

language. Some of social networking sites have been mentioned by the participants were Facebook, Instagram and WhatsApp as the following quotes.

"I used to use Facebook Group to help me reach more friends in learning English and helped me communicate. I also used Facebook in order to challenge my English skills, networking ability, and to find more English learners as my language learning supports, I use Facebook Group." (F3)

“... because I often open Instagram, so I follow some Instagram accounts that add new vocabulary, speaking or writing. So, I chose Instagram." (F2)

"WhatsApp can share pictures, video, documents, links and share the tasks." (M1)

Regarding the social networking site used for language learning, the finding showed that the participants mostly used Facebook, Instagram and WhatsApp as social networking sites they used to learn language because they found that these mobile applications could help them and gave positive effects for their language learning because these applications provided interesting features and could also be beneficial for their language learning process. This finding result go in same direction with the study of Faizi, (2017) who discovered that Web 2.0 technologies have a positive impact on language teaching and learning.

In this part, the participants have mentioned that the place that they mostly used for language learning were at home, dorm and formal class. Based on the interview sections, four of students said that the place they mostly used for learning language using mobile applications was their homes. On the other hand, two of participants mentioned on the interview sections that they mostly used mobile applications for learning language at dorm or formal class as illustrated on the following statements.

"Because I am undergraduate student and I mostly stay in the dorm for 4 years, I think I mostly use mobile applications at the dorm because if I have spare time, I will stay at the dorm" (M2)

"In formal class, because I love to talk with people and that really make me helped a lot by meeting with people and practice it together rather than alone by myself..." (M3)

The finding of place that participants mostly used for language learning showed different response. However, most of the participants chose their home as the place they mostly used to learn language using mobile applications. This finding is in line with the characteristics of mobile assisted language learning, availability that explained by Mehdipour and Zerehkafi (2013) cited in Klímová (2017).

Based on the length of using mobile applications per day, every participant had different answer for this question. They have mentioned that the length of time they used to learn language using mobile applications per day depended on their interest. In addition, every participant also gave various answers about the length of time they used mobile applications for language learning.
Tabel 1. Length of time using mobile applications per day for language learning

\begin{tabular}{rll}
\hline No. & Pre-service Teachers & \multicolumn{1}{c}{ Time per day } \\
\hline 1. & F1 & $2-3$ hours a day \\
2. & F2 & $3-4$ hours a day \\
3. & F3 & $1-2$ hours a day \\
4. & M1 & 30 minutes -1 hour a day \\
5. & M2 & 30 minutes -1 hour a day \\
6. & M3 & 1 day a week \\
\hline
\end{tabular}

Tabel 2. Length of time using mobile applications for language learning

\begin{tabular}{|c|c|c|}
\hline No. & $\begin{array}{c}\text { Pre-service } \\
\text { Teachers }\end{array}$ & Time \\
\hline 1. & F1 & Junior high school, 8 years ago \\
\hline 2. & $\mathrm{~F} 2$ & Elementary school \\
\hline 3. & F3 & $\begin{array}{l}\text { Junior High School, almost } 7 \\
\text { years ago. }\end{array}$ \\
\hline 4. & M1 & About $4-5$ years ago. \\
\hline 5. & M2 & $\begin{array}{l}\text { Senior high school, about } 5 \\
\text { years ago }\end{array}$ \\
\hline 6. & M3 & Senior high school \\
\hline
\end{tabular}

One of participants gave their explanations about the reasons the length of time of using mobile applications for language learning, as shown in the following statements.

"Since I got a quite useful mobile phone--android-that I can use to learn English. Specifically, I have been using mobile phone to learn English since I was in the third year of Junior High School. So, I think it's been almost 7 years. "' (F3)

According to data, most of the participants used mobile applications for more than an hour. This finding is different from the result of the research by Ahn (2018) cited in Thedpitak \& Somphong (2021) who revealed that most EFL Korean university students spent their time on mobile applications for less than one hour per day. In additions, the finding of the length of time using mobile applications for language learning showed that most of the participants used mobile applications for supporting language learning since they got their mobile devices that can support those mobile applications.

In this part, the researcher found the same answer from each of the participants about the differences when they learnt language using mobile applications. Each of the participants gave the same answers that said there were the differences when they learnt language using mobile applications and the differences consisted of positive and negative effects for them by using mobile applications, as the following quotes.

"Of course, in my opinion that would be easily for me to acquire language skill by following usual lecturing. I would be more confident to learn language through usual lecturing. I think I will be more lazy to learn 
Jurnal Edumaspul, 5 (2), Year 2021- 724

(Eka Ananda Putri ${ }^{1}$, Dadang Danugiri ${ }^{2}$, Fauzi Miftakh ${ }^{3}$ )

language trough mobile apps since there are so many bad possibilities like I feel unfamiliar with the mobile apps utilization, I have limited time and internet connection and limited opportunity to get guidance from the master like the lecture. I will have uncertain answer from the mobile app answering whenever I feel confused about something. " (F1)

"Yes, absolutely. Learning by using mobile applications allow me to learn more enjoy, flexible, and gain a lot of improvement. This is due to the fact that I study based on my willingness, both in choosing the material that I want to learn, and the time flexibility. In other words, using mobile applications allow me to learn something useful that I won't get from school." (M2)

The result showed that the participants found the differences between learning language using mobile applications and usual lecturing in both different perceptions. The half of the participants showed that the differences of using mobile applications are the enjoyments, the control and unlimited time they have to learn. This result is in line with Gafni, Achituv, \& Rachmani (2017) cited in Silva et al., (2019) who summarized the advantages of using mobile technology especially mobile applications for language learning are they have freedom and flexibility to use mobile devices for language learning in their time. Moreover, the other half of the participants showed the differences when learning using mobile applications are they cannot ask about material that they do not understand directly to the lectures and there is no guidance during learning process, but still think that mobile applications are also useful for their language learning process. These perceptions are supported by the result from Thedpitak \& Somphong (2021) who examined the issue of Thai EFL learners' attitudes toward the use of mobile applications for language learning and the result showed students' positive attitudes toward the use of mobile applications for language learning and suggested that the guidance from instructors to use mobile applications properly and effectively for students.

\section{Pre-service teachers' perceptions in using mobile applications for language learning \\ From questionnaire, the findings showed three} sections that explained about participants' perceptions on their use of mobile applications for language learning. The result about aim-mobile technologies fit (A-MTF) showed the highest mean score of aim-mobile technologies fit was 4.83 and it obtained for item 1 (Mobile applications remove the limitation of time and space) and the lowest mean score was 2.5 and it obtained for item 2 (Mobile applications do not generate effective learning-teaching environments). The result from appropriate of branch (AB) showed the highest score mean score of this section was for item 9 (Mobile applications are reliable for personal use) and the lowest mean score was for item 12 (Mobile applications is a good method for the interaction, which is necessary in my class). The result from forms of m-learning application and tools' sufficient adequacy of communication (FMA \& TSAC) showed the highest mean score was 4.83 for item 18 (Student- student communication is facilitated by means of Mobile applications) and the lowest mean score was for item 22 (Students can have more effective communication with Mobile applications than traditional methods).

Regarding the aim-mobile technologies fit (AMTF), the result showed that participants had positive perceptions about the use of mobile applications for supporting their language learning process because those could remove the limitation of time and space when they learn alone or discuss with their peers or lectures and mobile applications increase their motivations because they learn language based on their interest. These findings go in the same direction with the study Kim, Rueckert, Kim \& Seo (2013) who investigated the issue of Students' Perceptions and Experiences of Mobile Learning and the result showed that Mobile Assisted Language Learning opens up new pedagogical scaffoldings for students and gives many advantages for supporting their language learning process.

Another finding is appropriate of branch (AB) that showed all participants had positive perception about using mobile applications because those appropriate with their branchs and facilitate learning their subjects, appropriate for their personal use and needs, and help them to choose the method of learning by using mobile applications for their future class, as the participants are six pre-service teachers from English education department. These findings are supported by Ok and Ratliffe (2017) who conducted the research about use of mobile devices for English language learner students in the United States: a research synthesis and the result showed learning by using mobile devices could improve learning, self-efficacy, and engagement and increased students' time with the academic content which is similar to participants needs.

As for forms of m-learning application and tools' sufficient adequacy of communication (FMA and TSAC), participants showed positive perceptions about using mobile applications for communicating with peers or lectures in learning language process. However, the half of the participants still think that the guidance from lectures in learning still be needed. This finding is similar with the finding of Thedpitak \& Somphong (2021) who examined the issue of Thai EFL learners' attitudes toward the use of mobile applications for language learning and the results showed that learning language needed to be guided properly and effectively by lectures. 
Jurnal Edumaspul, 5 (2), Year 2021- 725

(Eka Ananda Putri ${ }^{1}$, Dadang Danugiri ${ }^{2}$, Fauzi Miftakh ${ }^{3}$ )

Tabel 3. Mobile perception learning scale

\begin{tabular}{|c|c|c|}
\hline Items & Aim-Mobile Technologies Fit (A-MTF) & Mean \\
\hline 1 & Mobile applications remove the limitation of time and space & 4.83 \\
\hline 2 & Mobile applications do not generate effective learning-teaching environments & 2.5 \\
\hline 3 & $\begin{array}{l}\text { Mobile applications is an effective method in exact transmission of knowledge } \\
\text { in learning activities }\end{array}$ & 3.67 \\
\hline 4 & Utilization of Mobile applications increases students' motivation & 3.67 \\
\hline 5 & $\begin{array}{l}\text { Applications such as WhatsApp and Zoom which are used through Mobile } \\
\text { applications, provide opportunity for discussions on subject without the } \\
\text { limitation of time and space }\end{array}$ & 3.67 \\
\hline 6 & $\begin{array}{l}\text { An effective learning environment could be produced by sending lecture notes } \\
\text { via Mobile applications such as E-mail or WhatsApp Messenger }\end{array}$ & 3.33 \\
\hline Items & Appropriate of Branch (AB) & Mean \\
\hline 7 & $\begin{array}{l}\text { I can have a prompt access to materials that I need which is related to my branch } \\
\text { by means of Mobile applications }\end{array}$ & 4.33 \\
\hline 8 & Mobile applications facilitate learning the subjects in my branch & 4.167 \\
\hline 9 & Mobile applications are reliable for personal use & 4.67 \\
\hline 10 & $\begin{array}{l}\text { I can use Mobile applications as a good discussion tool with my colleagues and } \\
\text { teachers in the learning activities }\end{array}$ & 4.33 \\
\hline 11 & Mobile applications is a good method in learning my specialized subject & 4 \\
\hline 12 & $\begin{array}{l}\text { Mobile applications is a good method for the interaction, which is necessary in } \\
\text { my class }\end{array}$ & 3.67 \\
\hline 13 & $\begin{array}{l}\text { I would like to supplement my classes in future with Mobile applications } \\
\text { method }\end{array}$ & 4.33 \\
\hline 14 & my specialized subject & 4 \\
\hline Items & $\begin{array}{l}\text { Forms of M-learning Application and Tools' Sufficient Adequacy of } \\
\text { Communication (FMA \& TSAC) }\end{array}$ & Mean \\
\hline 15 & Mobile applications can be used to supplement the traditional education & 4 \\
\hline 16 & $\begin{array}{l}\text { Learning activities can be realized by means of Mobile applications in e- } \\
\text { learning } \\
\text { Communication is possible in chat programs by means of Mobile applications }\end{array}$ & 4.33 \\
\hline 17 & $\begin{array}{l}\text { Course materials could be sent to students via Mobile applications } \\
\text { Teacher-student communication is facilitated by means of Mobile applications }\end{array}$ & 3.83 \\
\hline 18 & $\begin{array}{l}\text { Student-student communication is facilitated by means of Mobile applications } \\
\text { Learners can access the instructional websites with Mobile applications }\end{array}$ & 4.83 \\
\hline 19 & $\begin{array}{l}\text { Students can have more effective communication with Mobile applications than } \\
\text { traditional methods }\end{array}$ & 4.167 \\
\hline 20 & Teaching-Learning process should be performed any with Mobile applications & 3.83 \\
\hline 21 & & 4.33 \\
\hline 22 & & 2.83 \\
\hline 23 & & 3 \\
\hline
\end{tabular}




\section{Conclusion}

The aim of this study is to find out pre-service teachers' perceptions on the use of mobile applications. The result revealed that all participants have different levels of using mobile applications and have positive perceptions on the use of mobile applications for language learning. The result showed that even though they have different levels of using mobile applications, but they have positive perceptions about the advantages of using mobile applications for supporting language learning.

This study explains the benefits of using mobile applications for pre-service teachers and their levels of using mobile applications through interview and questionnaire. Thus, the researcher suggests for future researchers to do an observation for making the result more reliable and get better view of this study.

\section{References}

[1] Bastos, H. P. P., \& Machado, G. P. F. (2016). Dictionaries on Smartphones: Learners' Assessment of Features and Potential of Dictionary Apps as Pedagogical Tools. Á. Rocha et al. (eds.), New Advances in Information Systems and Technologies. DOI 10.1007/978-3319-31307-8_15.

[2] Braun, V., and Clarke, V. (2006). Using thematic analysis in psychology. Qualitative Research in Psychology, 3:2, 77-101. DOI: 10.1191/1478088706qp063oa.

[3] Chen, Y., Mayall, H.J., York, C.S., \& Smith, T.J. (2019). Parental perception and English Learners' mobile-assisted language learning: An ethnographic case study from a technology-based Funds of Knowledge approach. Learning, Culture and Social Interaction. https://doi.org/10.1016/j.1csi.2019.100325.

[4] Ekinci, E., \& Ekinci, M. (2017). Perceptions of EFL Learners about Using Mobile Applications for English Language Learning: A Case Study. International Journal of Language Academy. DOI: http://dx.doi.org/10.18033/ijla.3659.

[5] Faizi, R. (2017). Teachers' perceptions towards using Web 2.0 in language learning and teaching. Educ Inf Technol. Retrieved from https://doi.org/10.1007/s10639-017-9661-7.

[6] Hashim, H., Yunus, M.M., Embi, M, A., \& Ozir, N.A.M. (2017). Mobile-assisted Language
Learning (MALL) for ESL Learners: A Review of Affordances and Constraints.

SainsHumanika9: 1-5 (2017) 45-50.

[7] Heigham, J., \& Croker, R. A. (2009). Qualitative Research in Applied Linguistics A Practical Introduction. Palgrave Macmillan.

[8] Hsu, L. (2013). English as a foreign language learners' perception of mobile assisted language learning: a cross-national study. Computer Assisted Language Learning, 26:3, 197-213. Retrieved from doi: http://dx.doi.org/10.1080/09588221.2011.64948 $\underline{5}$.

[9] Kim, D., Rueckert, D., Kim, D.-J., \& Seo, D. (2013). Students' perceptions and experiences of mobile learning. Language Learning \& Technology, 17(3), 52-73. http://1lt.msu.edu/issues/october2013/kimetal.pd f.

[10] Klímová, B. (2017). Mobile phones and/or smartphones and their apps for teaching English as a foreign language. Educ Inf Technol. https://doi.org/10.1007/s10639-017-9655-5.

[11] Kukulska-Hulme, A. (2020). Mobile-Assisted Language Learning. The Encyclopedia of Applied Linguistics. DOI: 10.1002/9781405198431.wbeal0768.pub2.

[12] Kukulska-Hulme, A., \& Shield, L. (2008). An overview of mobile assisted language learning: From content delivery to supported collaboration and interaction. ReCALL, 20(3), 271-289. Doi:10.1017/S0958344008000335.

[13] Lake, V. E., Beisly, A. H. (2019). Translation Apps: Increasing Communication with Dual Language Learners. Early Childhood Education Journal https://doi.org/10.1007/s10643-01900935-7.

[14] Loewen, S., Crowther, D., Isbell, D. R., Kim, K. M., Maloney, J., Miller, Z. F. \&Rawal, H. (2019). Mobile-assisted language learning: A Duolingo case study. ReCALL First View, 1-19. https://doi.org/10.1017/S0958344019000065.

[15] Loewen, S., Isbell, D. R., \& Sporn, Z. (2020). The effectiveness of app-based language instruction for developing receptive linguistic knowledge and oral communicative ability. American Council on the Teaching of Foreign Languages. DOI: 10.1111/flan.12454.

[16] McCarty, S., Sato, T., \& Obari, H. (2017). Implementing Mobile Language Learning 
Technologies in Japan. Springer Briefs in Education. DOI 10.1007/978-981-10-2451-1.

[17] Miangah, T. M., \& Nezarat, A. (2012). MobileAssisted Language Learning. International Journal of Distributed and Parallel Systems (IJDPS), 3(1). DOI: 10.5121/ijdps.2012.3126.

[18] Ok, M. W., \& Ratliffe, K. T. (2017). Use of Mobile Devices for English Language Learner Students in the United States: A Research Synthesis. Journal of Educational Computing Research, $\quad 0(0) \quad 1-25 . \quad$ DOI: 10.1177/0735633117715748.

[19] Putri, H. F. H., Wijayanto, A. \& Supriyadi, S. (2020). Strengths and Weaknesses of SelfRegulated Learning through YouTube: Indonesian EFL Students' Perceptions. ELS Journal on Interdisciplinary Studies in Humanities, 3(4), 531-542. DOI: https://doi.org/10.34050/els- jish.v3i4.11749.

[20] Rueckert, D., Kiser, R., \& Cho, M. (2012). "Oral language assessment made easy via VoiceThread!". TESOL International Convention and English Language Expo, Philadelphia, PA, 28-3.

[21] Sabila, N. F., Pahlevi, M. R., \& Miftakh, F. (2020). Incorporating Edmodo as Learning Management System of Summative Assessment in EFL Classroom. ELTIN Journal, 8(2).

[22] Shosha, A. A. E. F.A., Mohamed, H. E., \& Fayed, S. A. E. H. (2019). Effect of (Mobile Based Learning Program) on Postgraduate Nursing Students' Satisfaction and Attitudes in Faculty of Nursing Damanhour University. American Journal of Nursing Research, 8(1), 114-121. DOI: 10.12691/ajnr-8-1-12.
[23] Silva, C., Melo, D., Barros, F., Conceição, J., Gonçalves, R., \& Au-Yong- Oliveira, M. (2019). Mobile Applications and Their Use in Language Learning. C. Silva et al. https://doi.org/10.1007/978-3-030-16187-3 44.

[24] Tai, Y. (2012). Contextualizing a MALL: practice design and evaluation. Educational Technology \& Society, 15(2), 220-230. http://www.ifets.info/journals/15 2/19.pdf.

[25] Thedpitak, A., \& Somphong, M. (2021). Exploring Thai EFL learners attitudes toward the use of mobile applications for language learning. LEARN Journal: Language Education and Acquisition Research Network, 14(1), 370-398.

[26] Uzunboylu, H., \& Özdaml,, F. (2011). Teacher perception for m-learning: Scale development and teachers' perceptions. Journal of Computer Assisted Learning, 27(6), 544556.https://doi.org/10.1111/j.13652729.2011 $.00415 . x$.

\section{About the Authors:}

Eka Ananda Putri is English Education student from Singaperbangsa University. Dadang Danugiri is a lecture in faculty of teacher training and education in Singaperbangsa University. Fauzi Miftakh is a lecture in faculty of teacher training and education in Singaperbangsa University. His interest research includes TEFL, Intercultural Language Learning, Teaching Reading, Speaking, and Applied Linguistics. 